\title{
Motor oil condition evaluation based on on-board diagnostic system
}

\author{
Lei WEI ${ }^{1}$, Haitao DUAN ${ }^{1}$, Dan JIA ${ }^{1}$, Yongliang JIN ${ }^{1}$, Song CHEN ${ }^{1}$, Lian LIU ${ }^{1}$, Jianfang LIU ${ }^{1,2}$, Xianming SUN ${ }^{1,3}$, \\ Jian LI ${ }^{1, *}$ \\ ${ }^{1}$ State Key Laboratory of Special Surface Protection Materials and Application Technology, Wuhan Research Institute of Materials Protection, \\ Wuhan 430030, China \\ ${ }^{2}$ College of Biological and Pharmaceutical Engineering, Wuhan Polytechnic University, Wuhan 430023, China \\ ${ }^{3}$ School of Materials Science and Engineering, Wuhan Institute of Technology, Wuhan 430073, China \\ Received: 06 February 2018 / Revised: 26 June 2018 / Accepted: 22 September 2018 \\ (C) The author(s) 2018. This article is published with open access at Springerlink.com
}

\begin{abstract}
The condition of the motor oil in civilian cars is difficult to monitor; hence, we propose a method to evaluate the degree of degradation of motor oil using an on-board diagnostic (OBD) system. Three civilian cars and four motor oils (containing mineral oils and synthetic oils) were subjected to five groups of road tests under urban traffic and high-way conditions. The operation information, oil service time, mileage, engine operation time, idle time of the engine, and number of start-ups of the engine were obtained using the proposed OBD system. Physiochemical properties and changes in the components of motor oils during road tests were analyzed in laboratory. The theoretical model of the comprehensive indicators of driving parameters and oil properties were established. The proposed method was successfully applied to different cars, motor oils, and operating conditions in road tests. All the theoretical models had high accuracy and precision. Herein, we provide a method to monitor the oil condition with real-time driving parameters and provide a reference for end users to change their motor oil reasonably.
\end{abstract}

Keywords: motor oil; oil condition evaluation; on-board diagnostic system

\section{Introduction}

Motor oil is an essential part of fuel-based vehicles. It provides wear protection, thermal management, and corrosion inhibition functions that are crucial for operation of the vehicle [1-3]. Regardless of the type of oil used in vehicles, degradation and/or contamination under complicated working conditions cannot be avoided [4-6]. Therefore, the motor oil must be changed to meet the normal working requirement. Although certain new energy vehicles have been developed, fuel-based vehicles continue to dominate the vehicle market. Fuel-based vehicles cannot be completely replaced in a short period of time. Excessively lengthy oil drain intervals increase wear in the engine and the likelihood of engine damage. If the intervals are too short, unnecessary preventive maintenance costs, energy wasting, and environment pollution are caused [7-10]. Study also shows that draining the motor oil too frequently may lead to a high concentration of additives in the oil. This can cause a reaction with the lubricant-surface and result in excessive wear [11]. Hence, a reasonable oil change interval is necessary for energy conservation, environment protection, and maintain cost saving.

Generally, there are two methods to determine the oil change interval. One method is sending oil samples to a laboratory to analyze the properties of the oil to determine whether the oil still meets certain criteria. The aforementioned oil analysis method can accurately

* Corresponding author: Jian LI, E-mail: lijianwuhan@tom.com 
determine the properties of oil; however, the long testing time and high cost limits its application [12-15]. Another more widely used method to change motor oil is based on the mileage or service time recommended by the original equipment manufacturers (OEM). As end users can easily monitor the miles that the vehicle has driven between oil change intervals, the recommended oil change interval has become widely accepted [16]. The recommended mileage that the OEM suggests for oil change intervals is based on various levels of severity of operation, which are rarely seen by consumers. It is impossible for the OEM to anticipate all operations of a user and list different oil drain intervals for each of them. In particular, most vehicles are used for more than one kind of operation. Hence, it is not easy to determine an optimum mileage for accurately changing motor oil [17-19]. Some scholars and OEMs attempt to use sensor technology to determine the oil life. Wang et al. [20] proposed a real-time sensor system that measures engine parameters and applies a special algorithm to indicate the oil drain interval. Jun et al. [21] applied the principal component analysis method to estimate the quality of vehicle engine oil based on oil viscosity indicators and certain engine operation parameters. General Motors has implemented an oil life monitoring system by monitoring the oil temperature and contaminations, and a penalty factor and engine speed are combined to simulate different operation speeds [22-26]. The application of such sensors and algorithms are limited due to cost, complexity, and limited utility of sensors and the errors caused by the algorithms. Jan Kral et al. [27] studied the features and qualities of 13 oil samples recommended for replacement by the onboard computer. The properties of kinematic viscosity, total base number, the amount of soot, oxidizing and sulphating products, water, fuel and glycol contamination, and high antioxidant presence were measured. The results did not correspond with the conclusions recommended by onboard computers.

Oil degradation is closely related to the operating conditions. The working load in the operation state and the idle state is different, which affects the working pressure of the engine oil. Frequently stopping and starting the engine results in continual oil temperature changes. Driving for short trips may cause unburned fuel and/or water to come into motor oil, which can reduce the viscosity and cause excessive wear of engine. Thus, it is necessary to establish the relation model between operation parameters and oil properties for scientifically determining motor oil change interval.

In this paper, a method to establish the theoretical model of operation parameters and oil properties based on road tests in urban traffic and high-way conditions was proposed. The theoretical model can directly reflect the change characteristics of motor oil properties with the operation parameters. This can be used to predict oil degradation in real-time based on the operation parameters of cars. This method can reduce the testing time and increase the accuracy for evaluating the oil change interval compared to the traditional laboratory oil analysis and stipulated operation mileage or service time, which helps change motor oil more economically and effectively.

\section{Experimental details}

The experimental cars and engine oils were tabulated in Table 1. The experimental cars include a 10 years old car (Experimental car No. 1), a 5 years old car (Experimental car No. 2), and a new car (Experimental car No. 3). All the experimental engines were port fuel injection-based and naturally aspirated. All the experimental cars were equipped with an on-board diagnostic (OBD) system. The OBD system was originally designed for monitoring emissions and fault diagnosis using a large number of sensors. The system can provide real-time operation information and trouble codes [28]. The OBD system has a connector for end users to access the diagnostic data. In this study, WiFi adapters are plugged into the OBD connector of cars, and the data can be manipulated using a cell phone application. Real-time engine operation time (EOT), mileage (MIL), service time (ST), engine idle time (EIT), and number of start-ups (NBS) were acquired using the OBD system and the cell phone application.

Oil samples were collected from the crankcase approximately every 30 days. Oil should be collected after the experimental cars stopped about half an hour. Collection via a vacuum tube inserted into the dipstick opening (sample a centimeter or two above the bottom of the oil pan). Sampling from the mid portion of the oil is preferable since the top and bottom portions are more likely to be contaminated, and 
Table 1 Experimental cars and motor oils.

\begin{tabular}{cccccc}
\hline No. & Experimental cars & $\begin{array}{c}\text { Displacement } \\
(\mathrm{L})\end{array}$ & Motor oils & $\begin{array}{c}\text { Oil change } \\
\text { mileage }(\mathrm{km})\end{array}$ & $\begin{array}{c}\text { Oil service } \\
\text { time }(\mathrm{d})\end{array}$ \\
\hline $1-1$ & Citroen Triomphe & 2 & API SL, SAE 5W-40 mineral oil special for Citroen engine & 5723 & 410 \\
$1-2$ & Citroen Triomphe & 2 & API SL, SAE 5W-40 mineral oil special for Citroen engine & 3883 & 165 \\
$2-1$ & Hyundai Verna & 1.4 & Havoline, API SL, SAE 5W-30 mineral oil & 6317 & 165 \\
$3-1$ & Buick Regal & 2 & API SN, SAE 5W-30 synthetic oil, special for GM & 4938 & 147 \\
$3-2$ & Buick Regal & 2 & Castrol Edge Professional SAE 5W-30 synthetic oil & 6471 & 154 \\
\hline
\end{tabular}

the mid portion is more likely to represent what is flowing through the lubrication system. The component changes of oxidation, nitration, sulfation, zinc dialkyldithiophosphate (ZDTP) of oils were tested using the Integra software of infrared spectrometer (NICOLET iS10, Thermo Fisher Scientific, US). Total acid number (TAN) of oil samples were tested with reference to the ASTM D974-2014 standard [29]. The oxidation onset temperature (OOT) was determined using differential scanning calorimeter (NETZSCH HP 204, Germany) with reference to the ASTM E 2009-02 (the heating rate was $10{ }^{\circ} \mathrm{C} / \mathrm{min}$, the oxidation pressure was $3.5 \mathrm{MPa}$, the flow rate of oxidation was $100 \mathrm{~mL} / \mathrm{min}$ ) [30].

\section{Results and discussion}

Experiment No. 1-1 was taken as an example to demonstrate the details of the analysis and modeling process. The driving parameters and oil properties of Experiment No. 1-1 are given in Table 2. The driving parameters, ST, MIL, EOT, ITE, and NBS, obtained using the OBD system can completely represent the operation state of the cars in the experiment. The physicochemical properties (TAN and OOT) and component changes of experimental oil (oxidation, nitration, sulfation, and ZDTP relative change values) directly reflect the motor oil degradation degree.

As shown in Table 2, the motor oil in Experiment No. 1-1was effective to 410 days and the experimental was driven for $5723 \mathrm{~km}$. The engine worked for $255.90 \mathrm{~h}$ and the idle time was $54.73 \mathrm{~h}$. The engine was started 545 times. The TAN of the new oil was $2.17 \mathrm{mgKOH} / \mathrm{g}$, which increased to $3.95 \mathrm{mgKOH} / \mathrm{g}$ after the experiment was concluded. The OOT value of the oil decreased from 243.7 to $198.9{ }^{\circ} \mathrm{C}$ during

Table 2 Driving parameters and oil properties of Experiment No.1-1.

\begin{tabular}{|c|c|c|c|c|c|c|c|c|c|c|}
\hline \multicolumn{5}{|c|}{ Driving parameters } & \multicolumn{6}{|c|}{ Oil properties } \\
\hline $\begin{array}{l}\text { ST } \\
\text { (d) }\end{array}$ & $\begin{array}{l}\text { MIL } \\
(\mathrm{km})\end{array}$ & $\begin{array}{l}\text { EOT } \\
\text { (h) }\end{array}$ & $\begin{array}{l}\text { ITE } \\
\text { (h) }\end{array}$ & NBS & $\begin{array}{c}\text { TAN } \\
(\mathrm{mgKOH} / \mathrm{g})\end{array}$ & $\begin{array}{l}\text { OOT } \\
\left({ }^{\circ} \mathrm{C}\right)\end{array}$ & $\begin{array}{l}\text { Oxidation } \\
\text { (A/0.1mm) }\end{array}$ & $\begin{array}{l}\text { Nitration } \\
(\mathrm{A} / 0.1 \mathrm{~mm})\end{array}$ & $\begin{array}{l}\text { Sulfation } \\
\text { (A/0.1mm) }\end{array}$ & $\begin{array}{c}\text { ZDTP } \\
(\mathrm{A} / 0.1 \mathrm{~mm})\end{array}$ \\
\hline 0 & 0 & 0.00 & 0.00 & 0 & 2.17 & 243.7 & 0.00 & 0.00 & 0.00 & 0.00 \\
\hline 47 & 769 & 36.77 & 6.73 & 82 & 2.29 & 232.1 & 0.05 & 0.05 & 0.04 & -0.07 \\
\hline 76 & 1390 & 62.30 & 10.96 & 135 & 2.42 & 224.5 & 0.06 & 0.07 & 0.06 & -0.09 \\
\hline 109 & 2013 & 88.90 & 16.59 & 196 & 2.80 & 220.0 & 0.08 & 0.10 & 0.08 & -0.11 \\
\hline 139 & 2424 & 105.27 & 20.39 & 232 & 2.93 & 216.6 & 0.09 & 0.12 & 0.10 & -0.12 \\
\hline 170 & 2862 & 124.43 & 24.58 & 269 & 3.11 & 213.3 & 0.10 & 0.14 & 0.11 & -0.12 \\
\hline 200 & 3333 & 145.13 & 29.02 & 313 & 3.26 & 212.3 & 0.11 & 0.17 & 0.12 & -0.12 \\
\hline 230 & 3858 & 169.37 & 34.32 & 360 & 3.44 & 209.3 & 0.12 & 0.20 & 0.14 & -0.13 \\
\hline 269 & 4226 & 182.93 & 37.19 & 389 & 3.53 & 208.5 & 0.14 & 0.22 & 0.15 & -0.13 \\
\hline 296 & 4587 & 199.10 & 41.09 & 423 & 3.62 & 204.1 & 0.13 & 0.23 & 0.16 & -0.13 \\
\hline 327 & 4918 & 212.02 & 43.57 & 449 & 3.66 & 202.1 & 0.14 & 0.25 & 0.17 & -0.13 \\
\hline 356 & 5054 & 220.05 & 45.73 & 465 & 3.72 & 201.0 & 0.14 & 0.26 & 0.17 & -0.13 \\
\hline 387 & 5405 & 236.55 & 49.60 & 502 & 3.83 & 199.7 & 0.14 & 0.26 & 0.16 & -0.14 \\
\hline 410 & 5723 & 255.90 & 54.73 & 545 & 3.95 & 198.9 & 0.15 & 0.30 & 0.19 & -0.14 \\
\hline
\end{tabular}


the road test. After the oil was used for 410 days, the oxidation, nitration and sulfation relative change values were $0.15 \mathrm{~A} / 0.1 \mathrm{~mm}, 0.30 \mathrm{~A} / 0.1 \mathrm{~mm}$ and $0.19 \mathrm{~A} / 0.1 \mathrm{~mm}$, respectively. The multifunctional additive $\mathrm{ZDTP}$ relative change value was $-0.14 \mathrm{~A} / 0.1 \mathrm{~mm}$. Four steps were applied by the proposed method to establish the theoretical model of operation parameters and oil properties.

The detailed description of every step of the analysis method is provided below.

Step 1: Data pre-processing.

The units and dimensions of the factors were different, and therefore, the original data obtained by the OBD system and the laboratory need processing before analysis. The average and initial values divided by original data are commonly used to pre-process data. In order to establish a theoretical model for oil degradation prediction, the initial value method was considered more suitable for this study. Some initial values of the factors (driving parameters, oxidation, nitration, sulfation, and ZDTP value) were 0 , which cannot be considered as a dividend. Thus, the driving parameters and oil properties of the road test in 47 days were considered as the initial value. The result of pre-processing the data of driving parameters and oil properties is illustrated in Table 3.

Step 2: Comprehensive indicator calculation.

This study attempted to establish a theoretical model between the comprehensive variation of driving parameters and the oil properties under different periods. The initial sequence was defined as the reference sequence $X_{0}$. The data in the subsequent experiment were defined as the comparability sequence $X_{i}$.

The absolute variation represented the change degree of the two groups of data. The change degree of the driving parameters and oil properties can be calculated with Eq. (1). The comprehensive indicator $\gamma_{i}$ was calculated with Eq. (2) for modeling data.

$$
\begin{gathered}
\Delta_{i}(k)=\left|x_{i}(k)-x_{0}(k)\right| \\
\gamma_{i}=\frac{1}{n} \sum_{k=1}^{n} \frac{1}{\Delta_{i}(k)}
\end{gathered}
$$

where $x_{0}(k)$ is the element of the reference sequence, $x_{i}(k)$ is the element of the comparability sequence, $\Delta_{i}(k)$ is the absolute variation of $x_{i}(k)$ and $x_{0}(k)$, and $n$ is the number of the elements. The driving parameters are considered as an example to present the details of the calculation process. The $X_{0}$ and $X_{1}$ (in Table 3) values were presented as follows.

$X_{0}(k)=\left[x_{0}(1), x_{0}(2), x_{0}(3), x_{0}(4), x_{0}(5)\right]=[1.0000,1.0000$, $1.0000,1.0000,1.0000]$

$X_{1}(k)=\left[x_{1}(1), x_{1}(2), x_{1}(3), x_{1}(4), x_{1}(5)\right]=[1.6170,1.8075$, $1.6943,1.6285,1.6463]$

\begin{tabular}{|c|c|c|c|c|c|c|c|c|c|c|c|}
\hline & \multicolumn{5}{|c|}{ Driving parameters } & \multicolumn{6}{|c|}{ Oil properties } \\
\hline & ST & MIL & EOT & ITE & NBS & TAN & OOT & Oxidation & Nitration & Sulfation & ZDTP \\
\hline$X_{0}$ & 1.0000 & 1.0000 & 1.0000 & 1.0000 & 1.0000 & 1.0000 & 1.0000 & 1.0000 & 1.0000 & 1.0000 & 1.0000 \\
\hline$X_{1}$ & 1.6170 & 1.8075 & 1.6943 & 1.6285 & 1.6463 & 1.0568 & 0.9673 & 1.2000 & 1.4000 & 1.5000 & 1.2857 \\
\hline$X_{2}$ & 2.3191 & 2.6177 & 2.4177 & 2.4651 & 2.3902 & 1.2227 & 0.9479 & 1.6000 & 2.0000 & 2.0000 & 1.5714 \\
\hline$X_{3}$ & 2.9574 & 3.1521 & 2.8629 & 3.0297 & 2.8293 & 1.2795 & 0.9332 & 1.8000 & 2.4000 & 2.5000 & 1.7143 \\
\hline$X_{4}$ & 3.6170 & 3.7217 & 3.3840 & 3.6523 & 3.2805 & 1.3581 & 0.9190 & 2.0000 & 2.8000 & 2.7500 & 1.7143 \\
\hline$X_{5}$ & 4.2553 & 4.3342 & 3.9470 & 4.3120 & 3.8171 & 1.4236 & 0.9147 & 2.2000 & 3.4000 & 3.0000 & 1.7143 \\
\hline$X_{6}$ & 4.8936 & 5.0169 & 4.6062 & 5.0996 & 4.3902 & 1.5022 & 0.9018 & 2.4000 & 4.0000 & 3.5000 & 1.8571 \\
\hline$X_{7}$ & 5.7234 & 5.4954 & 4.9750 & 5.5260 & 4.7439 & 1.5415 & 0.8983 & 2.8000 & 4.4000 & 3.7500 & 1.8571 \\
\hline$X_{8}$ & 6.2979 & 5.9649 & 5.4147 & 6.1055 & 5.1585 & 1.5808 & 0.8794 & 2.6000 & 4.6000 & 4.0000 & 1.8571 \\
\hline$X_{9}$ & 6.9574 & 6.3953 & 5.7661 & 6.4740 & 5.4756 & 1.5983 & 0.8707 & 2.8000 & 5.0000 & 4.2500 & 1.8571 \\
\hline$X_{10}$ & 7.5745 & 6.5722 & 5.9845 & 6.7949 & 5.6707 & 1.6245 & 0.8660 & 2.8000 & 5.2000 & 4.2500 & 1.8571 \\
\hline$X_{11}$ & 8.2340 & 7.0286 & 6.4332 & 7.3700 & 6.1220 & 1.6725 & 0.8604 & 2.8000 & 5.2000 & 4.0000 & 2.0000 \\
\hline$X_{12}$ & 8.7234 & 7.4421 & 6.9595 & 8.1322 & 6.6463 & 1.7249 & 0.8570 & 3.0000 & 6.0000 & 4.7500 & 2.0000 \\
\hline
\end{tabular}

Table 3 Processed data of driving parameters and oil properties for Experiment No. 1-1. 
According to Eq. (1), the absolute variation can be calculated as

$\Delta_{1}=[|1.6170-1.000|,|1.8075-1.0000|,|1.6943-1.0000|$, $|1.6285-1.0000|,|1.6463-1.0000|]=[0.6170,0.8075$, $0.6943,0.6285,0.6463]$.

$\gamma_{1}$ can be obtained with Eq. (2) as

$$
\begin{aligned}
\gamma_{1}= & \frac{1}{5} \sum_{k=1}^{5} \frac{1}{\Delta_{1}(k)}=\frac{1}{5} \times\left(\frac{1}{0.6170}+\frac{1}{0.8075}+\frac{1}{0.6943}\right. \\
& \left.+\frac{1}{0.6285}+\frac{1}{0.6463}\right)=1.4875
\end{aligned}
$$

With the same method, the $\gamma_{i}$ of the driving parameters and oil properties in different periods can be calculated (in Table 4).

Step 3: Establishing the theoretical model.

After the comprehensive indicators of driving parameters and oil properties were calculated, the theoretical model of driving parameters and oil properties was established. As shown in Fig. 1, the theoretical model of the comprehensive indicators of driving parameters and oil properties was $y=$ $6.2677 x+0.7334$, where $x$ is the comprehensive indicator of the driving parameters and $y$ is the comprehensive indicator of oil properties. The $R$ square of the theoretical model was 0.997 , which indicated the theoretical model represent the relation of data well $\left(R^{2}=\frac{\sum_{i=1}^{n}\left(\hat{y}_{i}-\bar{y}\right)^{2}}{\sum_{i=1}^{n}\left(y_{i}-\bar{y}\right)^{2}}\right.$, where $\hat{y}_{i}$ is the calculated value of theoretical model, $\bar{y}$ is the average value of the actual test value, and $y_{i}$ is the actual test value).

According to the criteria for changing gasoline engine oil of China (GB/T 8028-2010), oil should be

Table 4 Comprehensive indicators of driving parameters and oil properties.

\begin{tabular}{cccccc}
\hline $\begin{array}{c}\text { Time } \\
\text { (days) }\end{array}$ & $\begin{array}{c}\text { Driving } \\
\text { parameters }\end{array}$ & $\begin{array}{c}\text { Oil } \\
\text { properties }\end{array}$ & $\begin{array}{c}\text { Time } \\
\text { (days) }\end{array}$ & $\begin{array}{c}\text { Driving } \\
\text { parameters }\end{array}$ & $\begin{array}{c}\text { Oil } \\
\text { properties }\end{array}$ \\
\hline 76 & 1.4875 & 10.1925 & 269 & 0.2348 & 2.3436 \\
109 & 0.6967 & 4.8481 & 296 & 0.2106 & 2.0690 \\
139 & 0.5103 & 3.7639 & 327 & 0.1938 & 1.9480 \\
170 & 0.3969 & 3.1109 & 356 & 0.1838 & 1.8887 \\
200 & 0.3207 & 2.8722 & 387 & 0.1681 & 1.7963 \\
230 & 0.2644 & 2.4642 & 410 & 0.1540 & 1.7229 \\
\hline
\end{tabular}

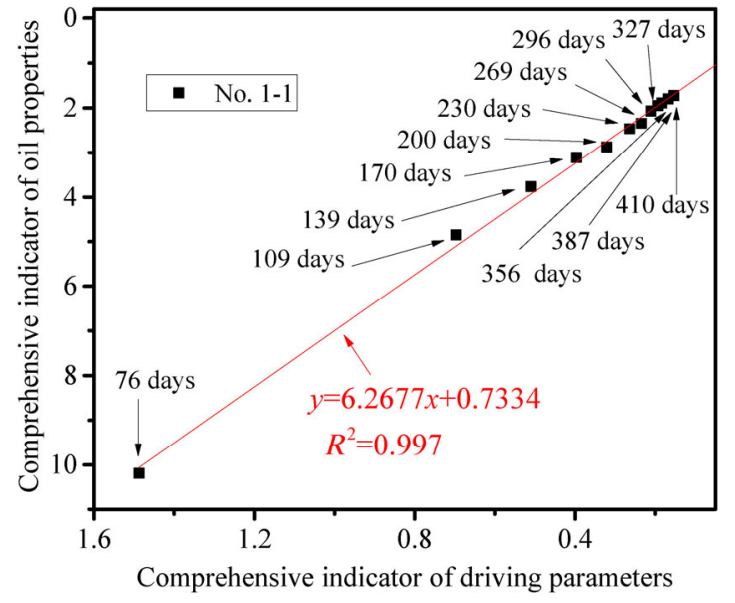

Fig. 1 Theoretical model for experiment No. 1-1.

changed when the increment of the TAN of motor oil reaches $2 \mathrm{mgKOH} / \mathrm{g}$. Thus, the motor oil used in Experiment No. 1-1 needs to be changed when the TAN increases to $4.17 \mathrm{mgKOH} / \mathrm{g}$. The oil properties of TAN reached $4.17 \mathrm{mgKOH} / \mathrm{g}$, which can be considered as the limiting value for draining the motor oil. As shown by the development trend of oil properties in Fig. 2, the OOT, oxidation, nitration, sulfation, and ZDTP values were $197.4{ }^{\circ} \mathrm{C}, 0.16 \mathrm{~A} / 0.1 \mathrm{~mm}$, $0.34 \mathrm{~A} / 0.1 \mathrm{~mm}, 0.20 \mathrm{~A} / 0.1 \mathrm{~mm}$, and $-0.15 \mathrm{~A} / 0.1 \mathrm{~mm}$, respectively, when the TAN reached $4.17 \mathrm{mgKOH} / \mathrm{g}$. The limiting comprehensive indicator of oil properties can be calculated with Eqs. (1) and (2), and it was found to be 1.6098 . The limiting comprehensive indicator of the driving parameters was 0.1398 , as calculated with the above established model. This suggests that the motor oil should be drained when the comprehensive indicator of driving parameters decreases to 0.1398 .

The road test for Experiment No. 1-2 was carried out with the same oil, experimental car, and the driver as used for Experiment No. 1-1. The average operation mileage per day for Experiment No. 1-2 $(23.53 \mathrm{~km} /$ day $)$ was larger than that for Experiment No. 1-1 (13.96 km/day). The driving parameters and oil properties are tabulated in Table 5. The oil used in Experiment No. 2-1 serviced 165 days, and the experimental cars operated $3883 \mathrm{~km}$ with 327 engine starts and stops. The engine operated for $165.70 \mathrm{~h}$, with $32.57 \mathrm{~h}$ in the idle state. After the road test was completed, the TAN of the experimental oil increased from 2.14 to $4.64 \mathrm{mgKOH} / \mathrm{g}$; the OOT value decreased 

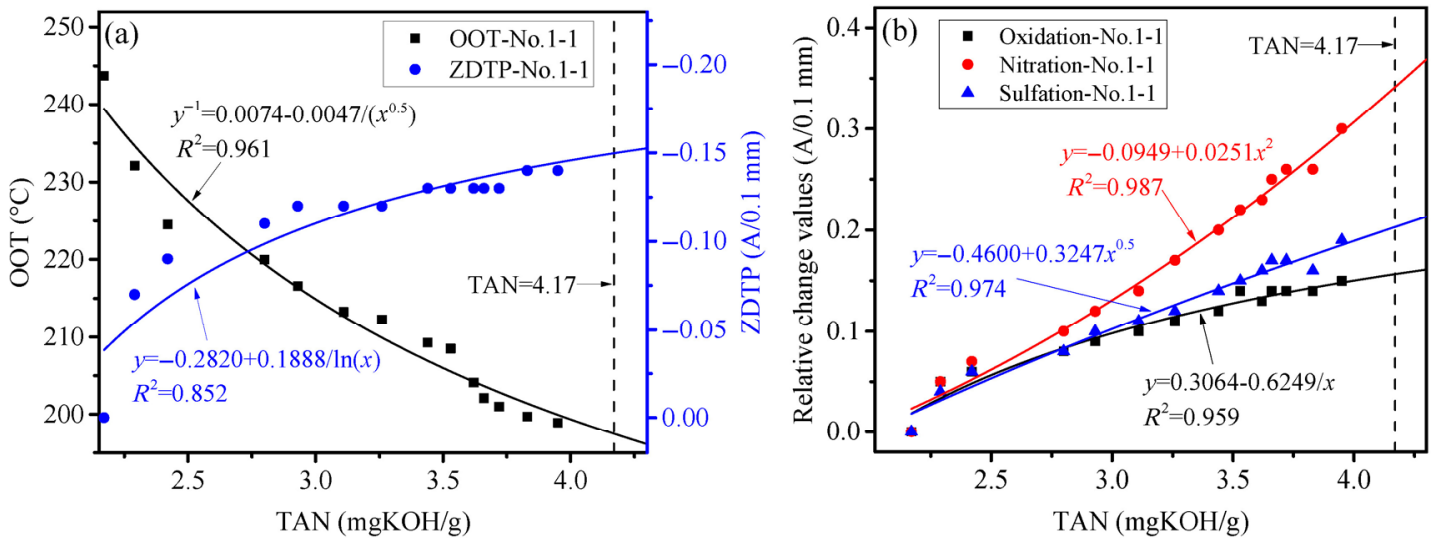

Fig. 2 Trend of oil properties for Experiment No. 1-1. (a) OOT and ZDTP; (b) oxidation value, nitration value and sulfation value.

Table 5 Driving parameters and oil properties for Experiment Nos. 1-2 and 2-1.

\begin{tabular}{|c|c|c|c|c|c|c|c|c|c|c|c|}
\hline \multirow[b]{2}{*}{ No. } & \multicolumn{5}{|c|}{ Driving parameters } & \multicolumn{6}{|c|}{ Oil properties } \\
\hline & $\begin{array}{l}\text { ST } \\
\text { (d) }\end{array}$ & $\begin{array}{l}\text { MIL } \\
(\mathrm{km})\end{array}$ & $\begin{array}{c}\text { EOT } \\
\text { (h) }\end{array}$ & $\begin{array}{l}\text { ITE } \\
\text { (h) }\end{array}$ & NBS & $\begin{array}{c}\text { TAN } \\
(\mathrm{mg} \mathrm{KOH} / \mathrm{g})\end{array}$ & $\begin{array}{l}\text { OOT } \\
\left({ }^{\circ} \mathrm{C}\right)\end{array}$ & $\begin{array}{l}\text { Oxidation } \\
(\mathrm{A} / 0.1 \mathrm{~mm})\end{array}$ & $\begin{array}{l}\text { Nitration } \\
(\mathrm{A} / 0.1 \mathrm{~mm})\end{array}$ & $\begin{array}{l}\text { Sulfation } \\
(\mathrm{A} / 0.1 \mathrm{~mm})\end{array}$ & $\begin{array}{c}\text { ZDTP } \\
(\mathrm{A} / 0.1 \mathrm{~mm})\end{array}$ \\
\hline \multirow{7}{*}{$1-2$} & 0 & 0 & 0.00 & 0.00 & 0 & 2.14 & 243.7 & 0.00 & 0.00 & 0.00 & 0.00 \\
\hline & 30 & 592 & 23.78 & 4.63 & 43 & 2.53 & 232.8 & 0.05 & 0.09 & 0.05 & -0.04 \\
\hline & 62 & 1264 & 53.90 & 10.48 & 105 & 2.87 & 223.4 & 0.06 & 0.12 & 0.03 & -0.06 \\
\hline & 90 & 2056 & 86.10 & 17.85 & 166 & 3.09 & 218.5 & 0.10 & 0.18 & 0.10 & -0.08 \\
\hline & 120 & 2664 & 112.50 & 22.23 & 212 & 3.83 & 215.4 & 0.11 & 0.21 & 0.12 & -0.10 \\
\hline & 153 & 3547 & 150.70 & 29.61 & 301 & 4.46 & 209.5 & 0.13 & 0.25 & 0.15 & -0.11 \\
\hline & 165 & 3883 & 165.70 & 32.57 & 327 & 4.64 & 209.0 & 0.14 & 0.27 & 0.16 & -0.11 \\
\hline \multirow{7}{*}{$2-1$} & 0 & 0 & 0.00 & 0.00 & 0 & 1.63 & 233.0 & 0.00 & 0.00 & 0.00 & 0.00 \\
\hline & 19 & 1125 & 34.37 & 7.46 & 73 & 1.78 & 223.5 & 0.04 & 0.06 & 0.04 & -0.04 \\
\hline & 48 & 2911 & 92.53 & 20.15 & 173 & 2.03 & 212.6 & 0.05 & 0.10 & 0.07 & -0.06 \\
\hline & 79 & 3886 & 134.10 & 28.05 & 265 & 2.12 & 209.5 & 0.05 & 0.12 & 0.07 & -0.09 \\
\hline & 108 & 4848 & 172.78 & 36.88 & 350 & 2.29 & 206.9 & 0.07 & 0.16 & 0.10 & -0.09 \\
\hline & 137 & 5628 & 197.07 & 41.00 & 411 & 2.39 & 205.6 & 0.08 & 0.18 & 0.12 & -0.12 \\
\hline & 156 & 6317 & 222.67 & 45.56 & 462 & 2.45 & 205.4 & 0.09 & 0.20 & 0.13 & -0.10 \\
\hline
\end{tabular}

from 243.7 to $209.0{ }^{\circ} \mathrm{C}$; and the oxidation, nitration, sulfation, and ZDTP relative change values were $0.14 \mathrm{~A} / 0.1 \mathrm{~mm}, 0.27 \mathrm{~A} / 0.1 \mathrm{~mm}, 0.16 \mathrm{~A} / 0.1 \mathrm{~mm}$, and $-0.11 \mathrm{~A} / 0.1 \mathrm{~mm}$, respectively. The driving parameters and oil properties of 30 days were considered as the reference sequence. The theoretical model was established with the method proposed above (Fig. 3). The theoretical model of the comprehensive indicators of driving parameters and oil properties of Experiment No. $1-2$ was $y=8.2795 x+0.7161$, where $x$ is the comprehensive indicator of the driving parameters and $y$ is the comprehensive indicator of the oil properties.
The $R$ square of the theoretical model was 0.999, which suggested that the theoretical model has high precision. The theoretical models for both Experiment Nos. 1-1 and 1-2 were high accuracy linear models.

The development trend of the oil properties of Experiment No. 1-2 (Fig. 4) can be determined with a similar method as that used for the Experiment No. 1-1. The OOT, oxidation, nitration, sulfation, and ZDTP values were $211.4{ }^{\circ} \mathrm{C}, 0.13 \mathrm{~A} / 0.1 \mathrm{~mm}, 0.24 \mathrm{~A} /$ $0.1 \mathrm{~mm}, 0.14 \mathrm{~A} / 0.1 \mathrm{~mm}$, and $-0.11 \mathrm{~A} / 0.1 \mathrm{~mm}$, respectively, when the TAN reached the criterion for oil change (2.14 $\mathrm{mgKOH} / \mathrm{g})$. The limiting comprehensive indicator 


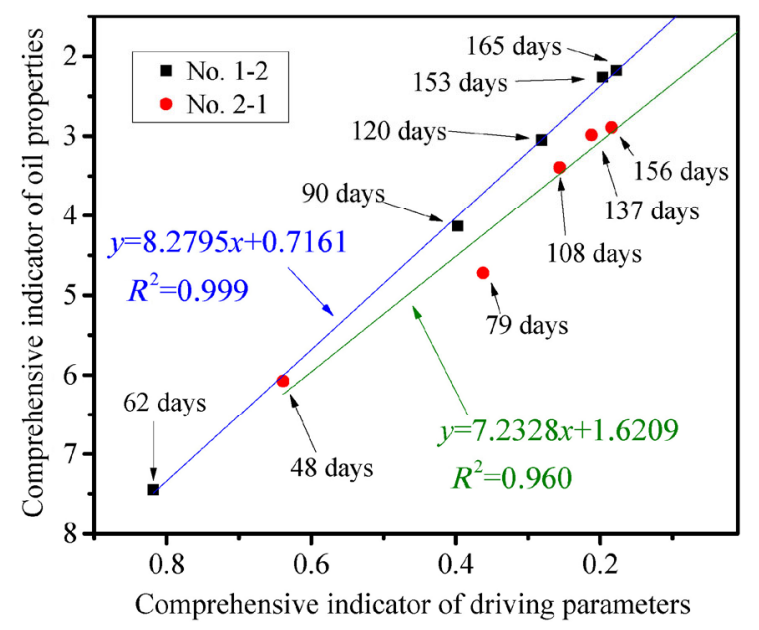

Fig. 3 Theoretical models for Experiment Nos. 1-2 and 2-1.

of the oil properties and driving parameters were 2.4670 and 0.2115 , which indicated that the motor oil should be drained when the comprehensive indicator decreased to 0.2115 . The established theoretical model has high precision even though the road test exceeded the limiting comprehensive value; this also demonstrated that the proposed method has good reliability.

Experiment No. 2-1 was carried out using Havoline mineral motor oil. The driving parameters and oil properties are presented in Table 5. Experiment No. 2-1 took 156 days, and the experimental cars operated for a total of $6317 \mathrm{~km}$. The engine operated for $222.67 \mathrm{~h}$, of which $45.56 \mathrm{~h}$ were in the idle state. The engine started 462 times during the experiment. The TAN of the oil used in Experiment No. 2-1 increased from 1.63 to $2.45 \mathrm{mgKOH} / \mathrm{g}$. The OOT value of the used oil was $205.4{ }^{\circ} \mathrm{C}$, which decreased by $27.6{ }^{\circ} \mathrm{C}$, compared to that for the new oil. The Integra results of the used oil show that the oxidation, nitration, sulfation, and
ZDTP relative change values were $0.09 \mathrm{~A} / 0.1 \mathrm{~mm}$, $0.20 \mathrm{~A} / 0.1 \mathrm{~mm}, 0.13 \mathrm{~A} / 0.1 \mathrm{~mm}$, and $-0.10 \mathrm{~A} / 0.1 \mathrm{~mm}$, respectively. The driving parameters and oil properties of 19 days were considered as the reference sequence. The theoretical model (Fig. 3) for Experiment No. 2-1 was $y=7.2328 x+1.6209$, where $x$ is the comprehensive indicator of driving parameters, and $y$ is the comprehensive indicator of oil properties. The $R$ square of the theoretical model was 0.960 , which indicated that the linear model has high accuracy for representing the data.

The development trend of the oil properties for Experiment No. 2-1 (as shown in Fig. 5) suggested that the OOT, oxidation, nitration, sulfation, and ZDTP values were $199.5^{\circ} \mathrm{C}, 0.15 \mathrm{~A} / 0.1 \mathrm{~mm}, 0.42 \mathrm{~A} / 0.1 \mathrm{~mm}$, $0.27 \mathrm{~A} / 0.1 \mathrm{~mm}$, and $-0.16 \mathrm{~A} / 0.1 \mathrm{~mm}$, respectively, when the TAN reached the criterion for oil change (3.63 $\mathrm{mgKOH} / \mathrm{g}$ ). The limiting comprehensive indicator of the oil properties (1.8854) and the driving parameters (0.0366) can be calculated with Eqs. (1) and (2). The motor oil needs to be changed while the comprehensive indicator decreases to 0.0366 .

Synthetic oil was also studied in this work. The oil used in Experiment No. 3-1 was synthetic oil, specially designed for GM engines. The oil used in Experiment No. 3-2 was the Castrol Edge Professional SAE 5W-30 synthetic oil. Two groups of experiments were carried out with the same experimental car and driver. The driving parameters and oil properties for Experiment Nos. 3-1 and 3-2 are presented in Table 6. The oil used in Experiment No. 3-1 serviced 147 days and the experimental car operated $4938 \mathrm{~km}$. The engine of the experimental car operated for $202.00 \mathrm{~h}$, and it was in the idle state for $43.44 \mathrm{~h}$. The increment of TAN
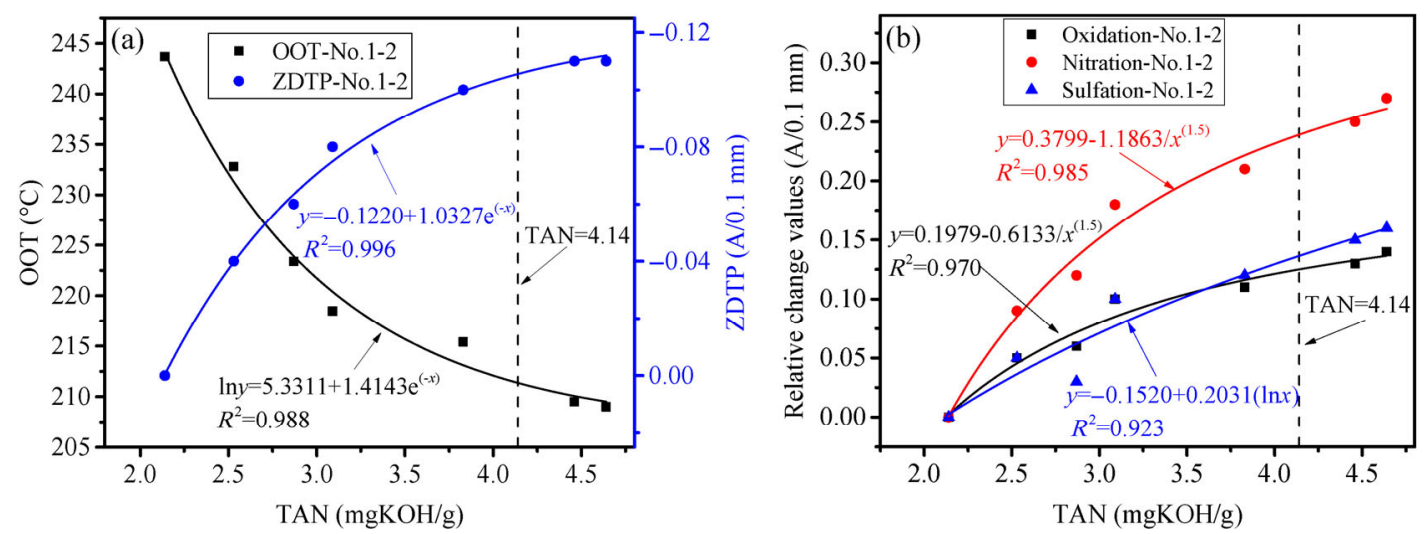

Fig. 4 Trend of oil properties for Experiment No. 1-2. (a) OOT and ZDTP; (b) oxidation value, nitration value and sulfation value. 

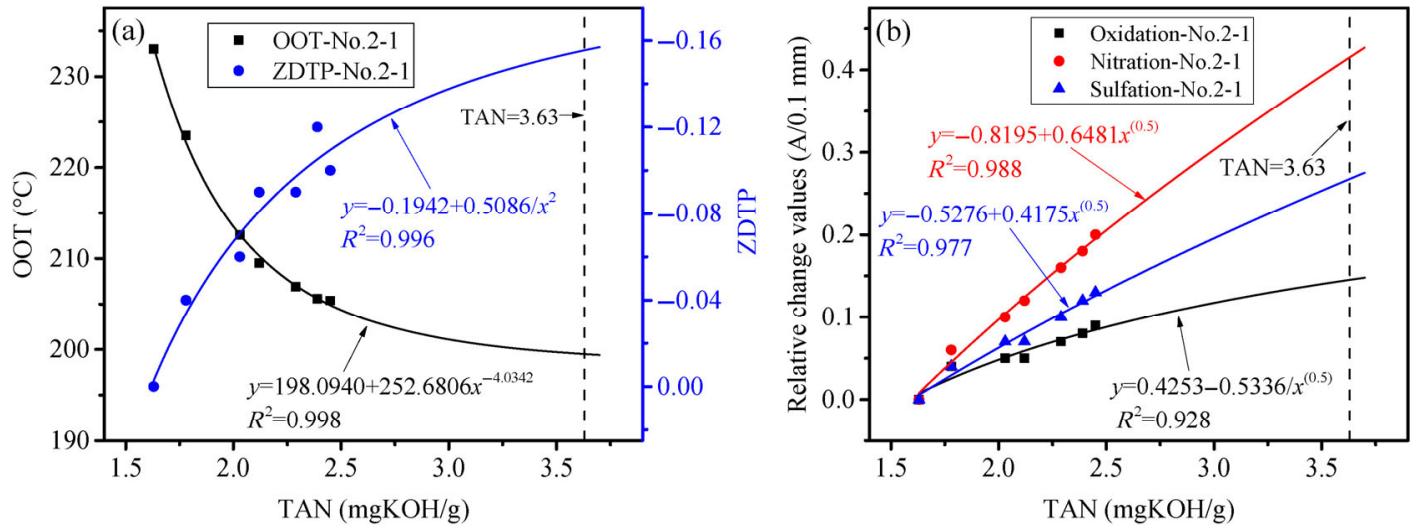

Fig. 5 Trend of oil properties for Experiment No. 2-1. (a) OOT and ZDTP; (b) oxidation value, nitration value and sulfation value.

Table 6 Driving parameters and oil properties for Experiment Nos. 3-1 and 3-2.

\begin{tabular}{|c|c|c|c|c|c|c|c|c|c|c|}
\hline \multirow[b]{2}{*}{ No. } & \multicolumn{5}{|c|}{ Driving parameters } & \multicolumn{5}{|c|}{ Oil properties } \\
\hline & $\begin{array}{l}\text { ST } \\
\text { (d) }\end{array}$ & $\begin{array}{l}\text { MIL } \\
(\mathrm{km})\end{array}$ & $\begin{array}{c}\text { EOT } \\
\text { (h) }\end{array}$ & $\begin{array}{l}\text { ITE } \\
\text { (h) }\end{array}$ & NBS & $\begin{array}{c}\text { TAN } \\
(\mathrm{mgKOH} / \mathrm{g})\end{array}$ & $\begin{array}{l}\text { OOT } \\
\left({ }^{\circ} \mathrm{C}\right)\end{array}$ & $\begin{array}{l}\text { Oxidation } \\
(\mathrm{A} / 0.1 \mathrm{~mm})\end{array}$ & $\begin{array}{l}\text { Nitration } \\
(\mathrm{A} / 0.1 \mathrm{~mm})\end{array}$ & $\begin{array}{l}\text { Sulfation } \\
\text { (A/0.1mm) }\end{array}$ \\
\hline \multirow{7}{*}{$3-1$} & 0 & 0 & 0.00 & 0.00 & 0 & 1.69 & 256.0 & 0.00 & 0.00 & 0.00 \\
\hline & 23 & 695 & 36.90 & 7.80 & 66 & 1.74 & 242.9 & 0.03 & 0.04 & 0.03 \\
\hline & 54 & 1880 & 82.90 & 15.81 & 141 & 1.99 & 236.4 & 0.04 & 0.07 & 0.04 \\
\hline & 83 & 2609 & 129.72 & 25.84 & 209 & 2.28 & 230.6 & 0.06 & 0.10 & 0.07 \\
\hline & 114 & 4118 & 167.22 & 35.33 & 285 & 2.47 & 225.3 & 0.06 & 0.11 & 0.07 \\
\hline & 143 & 4821. & 198.00 & 42.63 & 347 & 2.50 & 221.6 & 0.08 & 0.16 & 0.10 \\
\hline & 147 & 4938 & 202.00 & 43.44 & 356 & 2.54 & 220.4 & 0.10 & 0.17 & 0.11 \\
\hline \multirow{6}{*}{$3-2$} & 0 & 0. & 0.00 & 0.00 & 0 & 1.55 & 239.7 & 0.00 & 0.00 & 0.00 \\
\hline & 25 & 544 & 21.50 & 4.40 & 51 & 1.62 & 236.2 & 0.03 & 0.05 & 0.02 \\
\hline & 59 & 986 & 36.73 & 7.64 & 85 & 1.67 & 233.7 & 0.05 & 0.07 & 0.03 \\
\hline & 93 & 4552 & 100.98 & 15.86 & 175 & 2.12 & 226.3 & 0.08 & 0.12 & 0.04 \\
\hline & 123 & 5710 & 134.95 & 22.54 & 236 & 2.24 & 224.5 & 0.10 & 0.14 & 0.05 \\
\hline & 154 & 6471 & 171.48 & 31.19 & 311 & 2.34 & 222.0 & 0.11 & 0.17 & 0.06 \\
\hline
\end{tabular}

for the Experiment No. 3-1 oil was small, increasing from 1.69 to $2.54 \mathrm{mgKOH} / \mathrm{g}$; the OOT decreased from 256.0 to $220.4{ }^{\circ} \mathrm{C}$; and the oxidation, nitration, and sulfation relative change values were $0.10 \mathrm{~A} / 0.1 \mathrm{~mm}$, $0.17 \mathrm{~A} / 0.1 \mathrm{~mm}$, and $0.11 \mathrm{~A} / 0.1 \mathrm{~mm}$, respectively. The driving parameters and oil properties for 23 days were considered as the reference sequence. The theoretical model (as shown in Fig. 6) for Experiment No. 3-1 was $y=12.4997 x+0.2813$, where $x$ is the comprehensive indicator of the driving parameters and $y$ is the comprehensive indicator of the oil properties. The $R$ square of the theoretical model was 0.997 , which suggested that the theoretical model was reliable and accurate. The trend of oil properties of No. 3-1 experiment (Fig. 7) illustrated the OOT value, oxidation value, nitration value, and sulfation value were $210.0{ }^{\circ} \mathrm{C}, 0.20 \mathrm{~A} / 0.1 \mathrm{~mm}, 0.38 \mathrm{~A} / 0.1 \mathrm{~mm}$, and $0.27 \mathrm{~A} / 0.1 \mathrm{~mm}$, respectively, when the TAN reached to criterion for oil changing (3.69 $\mathrm{mgKOH} / \mathrm{g})$. The limiting comprehensive indicator of oil properties (1.7389) and driving parameters (0.1166) can be calculated with Eqs. (1) and (2). The motor oil need to be changed while the comprehensive indicator decrease to 0.1166 .

The oil in Experiment No. 3-2 serviced for 154 days and the experimental car operated for $6471 \mathrm{~km}$. The engine started 311 times during the $171.48 \mathrm{~h}$ of operation time, of which the idle time was $31.19 \mathrm{~h}$. 


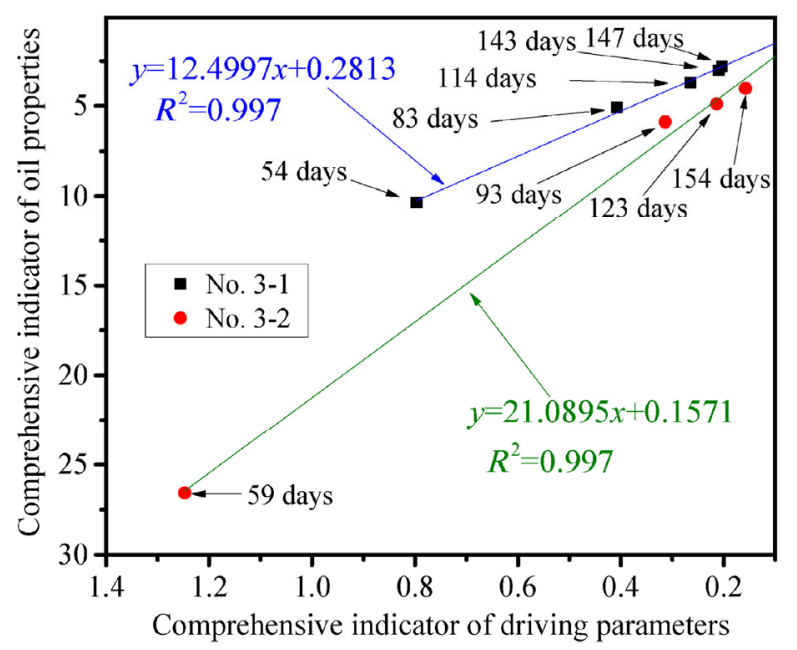

Fig. 6 Theoretical models for Experiment Nos.3-1 and 3-2.

The TAN of Experiment No. 3-2 oil increased from 1.55 to $2.34 \mathrm{mgKOH} / \mathrm{g}$, and the OOT decreased from 239.7 to $222.0^{\circ} \mathrm{C}$. After the experiment was completed, the oxidation, nitration, and sulfation relative change values were $0.11 \mathrm{~A} / 0.1 \mathrm{~mm}, 0.17 \mathrm{~A} / 0.1 \mathrm{~mm}$, and
$0.06 \mathrm{~A} / 0.1 \mathrm{~mm}$, respectively. The driving parameters and oil properties of 25 days were considered as the reference sequence. The theoretical model (Fig. 6) of Experiment No. 3-2 was $y=21.0895 x+0.1571$, where $x$ is the comprehensive indicator of the driving parameters and $y$ is the comprehensive indicator of oil properties. The $R$ square of the theoretical model was 0.997, indicating that the theoretical model represented the data well.

The development trend of the oil properties for Experiment No. 3-2, as shown in Fig. 8, indicates that the OOT, oxidation, nitration, and sulfation values are $216.1{ }^{\circ} \mathrm{C}, 0.15 \mathrm{~A} / 0.1 \mathrm{~mm}, 0.23 \mathrm{~A} / 0.1 \mathrm{~mm}$, and 0.09 $\mathrm{A} / 0.1 \mathrm{~mm}$, respectively, when the TAN reaches the criterion for oil change $(3.55 \mathrm{mgKOH} / \mathrm{g})$. The limiting comprehensive indicator of oil properties (2.6808) and driving parameters (0.1197) can be calculated with the Eqs. (1) and (2). The motor oil needs to be changed when the comprehensive indicator decreases to 0.1197 .
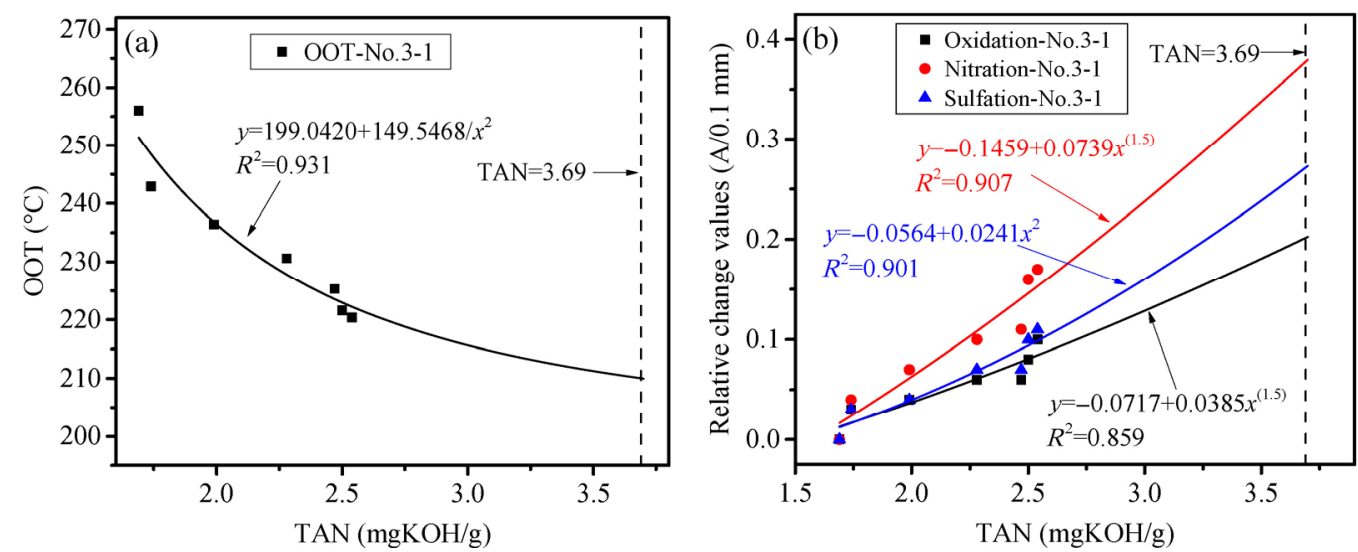

Fig. 7 Trend of oil properties for Experiment No. 3-1. (a) OOT; (b) oxidation value, nitration value, and sulfation value.
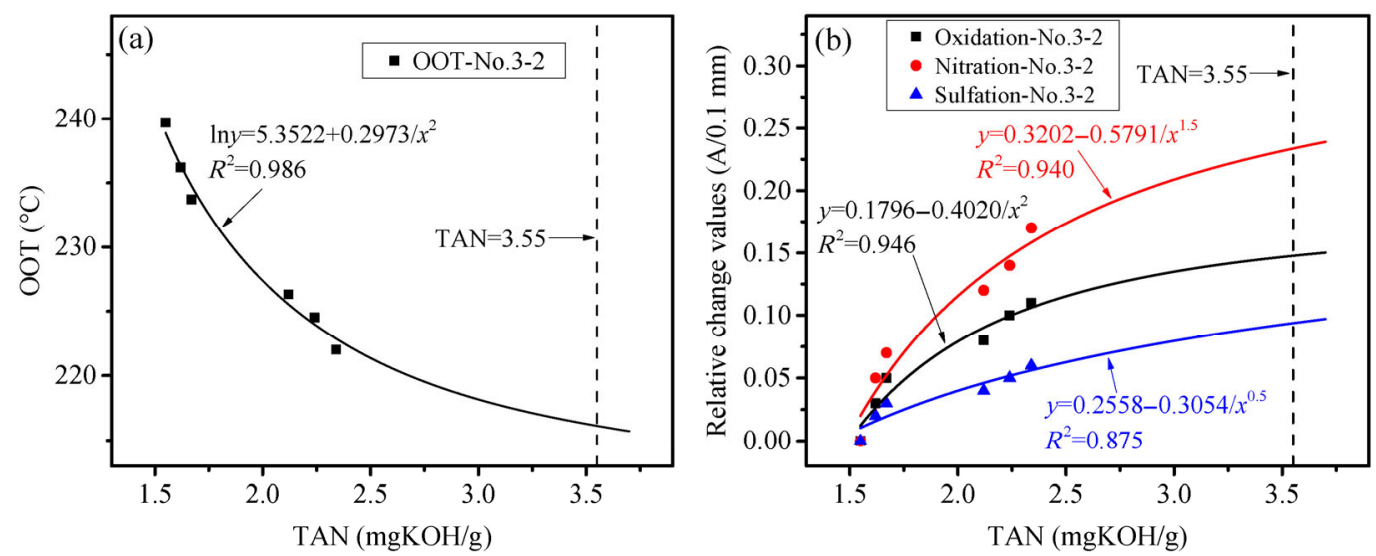

Fig. 8 Trend of oil properties for Experiment No. 3-2. (a) OOT; (b) oxidation value, nitration value, and sulfation value. 
As per the operation information and oil properties presented in Tables 2, 5, and 6, the OOT values of synthetic oils were larger than $220{ }^{\circ} \mathrm{C}$ after the oils serviced more than $4938 \mathrm{~km}$ and $6471 \mathrm{~km}$, which was higher than that for mineral oils (approximately $200{ }^{\circ} \mathrm{C}$ ). It is suggested that the oxidation stabilities of the experimental synthetic oils were better than those of mineral oils. The increments of the TAN of synthetic oils were smaller than that of the mineral oils, which indicated the advantages of the synthetic oil in reducing the production of acid products. The experimental synthetic oils have better comprehensive performance than the experimental mineral oils.

The average speed and idle ratios of the experiments are shown in Fig. 9. Since the Experiment Nos.1-1, 1-2, 2-1, and 3-1 were conducted under urban traffic conditions, the average speeds for these experiments were $22.36 \mathrm{~km} / \mathrm{h}, 23.43 \mathrm{~km} / \mathrm{h}, 28.37 \mathrm{~km} / \mathrm{h}$, and $24.45 \mathrm{~km} / \mathrm{h}$, respectively. Experiment Nos. 1-1, 1-2, 2-1, and 3-1 have the characteristics of high idle ratios and low operation speeds, which are typical urban traffic conditions. The average speed for Experiment Nos. $1-1,1-2,2-1$, and 3-1 were consistent with the average speeds of civilian cars in China's major cities (approximately $20-27 \mathrm{~km} / \mathrm{h}$ ). The Experiment No. 3-2 was carried out under urban and highway traffic conditions; the average speed for this experiment was $37.74 \mathrm{~km} / \mathrm{h}$, and the idle ratio was $18.2 \%$. The average speed was higher and the idle ratio was smaller compared with those suitable for urban traffic conditions. All $R$-square values of the established theoretical models were larger than 0.96 , which suggested that the proposed method used to establish the theoretical

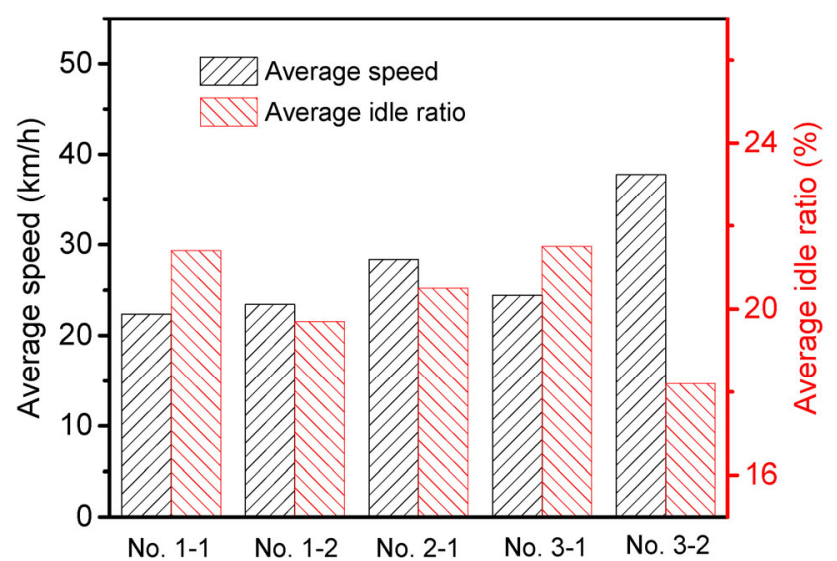

Fig. 9 Average speed and average idle ratio of the experiments. model between the driving parameters and oil properties had high accuracy and precision in both experimental mineral oils and synthetic oils under urban traffic and highway conditions.

\section{Conclusions}

This study was based on 41 oil samples in three experimental cars during the 575 days of road tests. The conclusions were as follow:

1) A method was proposed to establish the theoretical models of the comprehensive change characteristics of the driving parameters and oil properties. The proposed method has high accuracy and precision for both mineral and synthetic oils under urban traffic and highway conditions. The proposed method can help realize real-time oil condition monitoring with operation parameters obtained by the OBD system.

2) The results of the road tests in this study verified that the synthetic oils have better ability to restrain the increase of acid products and decrease oxidation stability compared to that of mineral oils. The oil change interval can also be appropriately extended by using the synthetic oil.

\section{Acknowledgements}

The authors are grateful for the financial support from the National Natural Science Foundation of China (No. 51575402).

Open Access: The articles published in this journal are distributed under the terms of the Creative Commons Attribution 4.0 International License (http:// creativecommons.org/licenses/by/4.0/), which permits unrestricted use, distribution, and reproduction in any medium, provided you give appropriate credit to the original author(s) and the source, provide a link to the Creative Commons license, and indicate if changes were made.

\section{References}

[1] Klowak M, Gracyalny G. Engine oil recirculation system for extended maintenance interval. U.S. Patent 20150053505, 
Feb. 2015.

[2] Wei L, Duan H T, Chen S, Jia D, Qian X Z, Cheng B X, Liu J F, Li J. A field test method to quantitatively determine oxidation stability of gasoline engine oil. Lubricat Sci 30(2): 57-64 (2018)

[3] Kader M K, Ramani T, Jacobs T J. Effect of extended idle on oil degradation rates of heavy-duty vehicles. Int J Heavy Veh Syst 22(3): 193-212 (2015)

[4] Yüksek L. Optimization of the oil drain interval of nonphosphorus and non-ash engine oil. Ind Lubr Tribol 68(4): 497-507 (2016)

[5] Langfitt Q, Haselbach L. Coupled oil analysis trending and life-cycle cost analysis for vessel oil-change interval decisions. J Mar Eng Technol 15(1): 1-8 (2016)

[6] Zhu X L, Zhong C, Zhe J. Lubricating oil conditioning sensors for online machine health monitoring-a review. Tribol Int 109: 473-484 (2017)

[7] Holmberg K, Erdemir A. Influence of tribology on global energy consumption, costs and emissions. Friction 5(3): 263-284 (2017)

[8] Qian X Z, Xiang Y L, Shang H F, Cheng B X, Zhan S P, Li J. Thermal-oxidation mechanism of dioctyl adipate base oil. Friction 4(1): 29-38 (2016)

[9] Puckace J A, Redmon J J, Fitzgerald H, Ismail O K. Method of determining optimal change interval for a functional fluid. U.S. Patent 20130046433, Feb. 2013.

[10] Gulzar M, Masjuki H H, Varman M, Kalam M A, Zulkifli N W M, Mufti R A, Liaquat A M, Zahid R, Arslan A. Effects of biodiesel blends on lubricating oil degradation and piston assembly energy losses. Energy 111: 713-721 (2016)

[11] Youngk R D. Automobile engine reliability, maintainability and oil maintenance. In Proceedings of Annual Reliability and Maintainability Symposium. 2000 Proceedings. International Symposium on Product Quality and Integrity, Los Angeles, CA, USA, 2000: 94-99.

[12] Ahmed N S, Nassar A M, Abdel-Hameed H S, El-Kafrawy A F. Preparation, characterization, and evaluation of some ashless detergent/dispersant additives for lubricating engine oil. Appl Petrochem Res 6(1): 49-58 (2016)

[13] Timotijevic Z, Bacevac S, Corsi S. Evaluation of oil drain interval for buses in urban traffic with respect to local operating conditions. In Proceedings of World Tribology Congress, Torino, Italy, 2013.

[14] Rudnick L R. Summary of lubricant standard test methods and some product specifications. In Lubricant Additives: Chemistry and Applications. Rudnick L R, Ed. Bosa Roca: CRC Press, 2003: 599-616.
[15] Thom R, Kollmann K, Warnecke W, Frend M. Extended oil drain intervals: Conservation of resources or reduction of engine life. SAE Trans 104(4): 706-718 (1995)

[16] Mesgarpour M, Landa-Silva D, Dickinson I. Overview of telematics-based prognostics and health management systems for commercial vehicles. In Proceedings of the 13th International Conference on Transport Systems Telematics, Katowice-Ustroń, Poland, 2013: 123-130.

[17] Sejkorová M, Hurtová I, Glos J, Pokorný J. Definition of a motor oil change interval for high-volume diesel engines based on its current characteristics assessment. Acta Univ Agric Silvic Mendelianae Brun 65(2): 481-490 (2017)

[18] Mamgbi R, Cerny J, Barifaijo E. Time of Exploitation and Detergency Properties of Low Saps Engine Oil. Nafta-Gaz 69(1): 57-65 (2013)

[19] Sharma B K, Stipanovic A J. Development of a new oxidation stability test method for lubricating oils using high-pressure differential scanning calorimetry. Thermochim Acta 402(1-2): 1-18 (2003)

[20] Wang J C, Whitacre S D, Schneider M L, Dringenburg D H. System and method for determining oil change interval. U.S. Patent 6,253,601, Jul. 2001.

[21] Jun H B, Conte F L, Kiritsis D, Xirouchakis P. A predictive algorithm for estimating the quality of vehicle engine oil. Int J Ind Eng Theory Appl Pract 15(4): 386-396 (2008)

[22] Schwartz E S, Smolenski D J, Wisehart A J, Nguyen T N. Automatic engine oil change indicator system. U.S. Patent 4742476, May 1988.

[23] Schwartz E S, Smolenski D J, Keersmaekers J D, Traylor C M, Wallo G J. Automatic engine oil change indicator system. U.S. Patent 4847768, Jul. 1989.

[24] Mc Donald J E, Schwartz E S, Hamparian N, Jacek M, Stempnik J M, Fletcher S J. Oil life monitor for diesel engines. U.S. Patent 6327900, Dec. 2001.

[25] Schwartz S E. A model for the loss of oxidative stability of engine oil during long-trip service, Part I: Theoretical considerations. Tribol Trans 35(2): 235-244 (1992)

[26] Schwartz S E. A model for the loss of oxidative stability of engine oil during long-trip service, Part II: Vehicle measurements. Tribol Trans 35(2): 307-315 (1992)

[27] Kral Jr J, Konecny B, Kral J, Madac K, Fedorko G, Molnar V. Degradation and chemical change of longlife oils following intensive use in automobile engines. Measurement 50: $34-42$ (2014)

[28] Siegel J, Bhattacharyya R, Deshpande A, Sarma S. Vehicular engine oil service life characterization using On-Board Diagnostic (OBD) sensor data. In Proceedings of 2014 IEEE 
SENSORS, Valencia, Spain, 2014: 1722-1725.

[29] US-ASTM. ASTM D974-2014 Standard test method for acid and base number by color-indicator titration. ASTM, 2014.

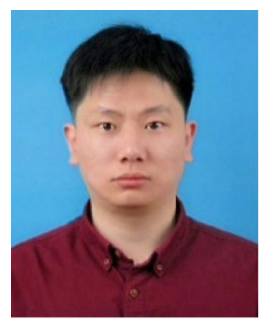

Lei WEI. He obtained his bachelor degree in 2011 from Wuhan Textile University and Ph.D degree in 2018 from Wuhan Research Institute of

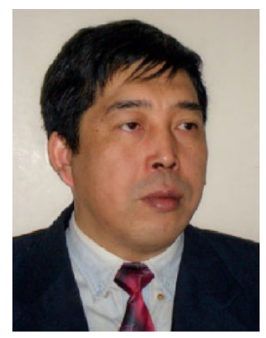

Jian LI. He is a professor, obtained his master degree in 1995 from Xi'an Jiaotong University. He is the vicechief engineer of Wuhan Research
[30] ASTM International. ASTM E2009-02 Standard test method for oxidation onset temperature of hydrocarbons by differential scanning calorimetry. West Conshohocken, PA: 19428-2959 ASTM International, 2002.

Materials Protection. His research areas include motor oil life monitoring and oil degradation analysis. He has participated in many research projects.

Institute of Materials Protection. His research interests cover the surface coating, lubricating materials, and tribological testing technology. 